Natural Hazards and Earth System Sciences (2003) 3: 625-635

(C) European Geosciences Union 2003

Natural Hazards and Earth System Sciences

\title{
A historical analysis of hazardous events in the Alps - the case of Hindelang (Bavaria, Germany)
}

\author{
F. Barnikel ${ }^{1}$ and M. Becht ${ }^{2}$ \\ ${ }^{1}$ Department of Geo- and Environmental Sciences, Geography Section, University of Munich, Luisenstrasse 37, 80333 \\ Munich, Germany \\ ${ }^{2}$ Institute for Geography, University of Goettingen, Goldschmidtstrasse 5, 37077 Goettingen, Germany
}

\begin{abstract}
A historical analysis of natural hazards for the Hindelang area in the Bavarian Alps is done by researching and assessing data from different archives. The focus is on an evaluation of historical hazards on a local scale by working with written documents only. Data is compiled from the archives of governmental departments, local authorities, private collections and state archives. The bandwidth of the assessed hazards includes floods, mass movements and snow avalanches. So far we have collected more than 400 references for events in the Hindelang area, some of which at times or in places where natural hazards used to be thought of as unlikely or unknown. Our aim was to collect all written data for this area and to deduce as much information on the hazardous effects on the environment as possible, thereby enhancing our knowledge about past climatic and geomorphic dynamics in the Alps.
\end{abstract}

\section{The aim of HANG}

The project HANG (Historische Analyse von NaturGefahren/Historical analysis of natural hazards) at the Universities of Munich and Goettingen deals with the historical analysis of natural hazards in the Alps. The research work focuses on hydrological features like floods, debris-flows, geomorphic/geological events (like rock falls and land slides) and snow avalanches.

At all times in the past extreme natural incidents have hit the Alps. Most of these incidents, especially when dating back several decades or even centuries, are hardly remembered by people. In such cases one can try to gather not only classical scientific data, but also contemporary written documents. HANG works with written documents, maps and (as is the case with some of the younger references) photographs on past hazardous events. The relevant public and private archives of the study areas are thoroughly scrutinized. Find-

Correspondence to: F. Barnikel

(barnikel@geographie.uni-muenchen.de) ings are listed in a data bank and visualized in maps of natural hazards in the area. The results of this meticulous analysis lead to a more profound knowledge about the regional differentiation of hydrological and geomorphic dynamics in the Alps. Thereby, future planning and measures of protection in the regions will stand on a broader basis of knowledge. The fact that HANG is the first project only concentrating on all kinds of incidents occurring in a relatively small catchment area by analysing textual or related documents only makes it unique.

\section{The Hindelang area}

The Hindelang area is situated in the Allgäu part of the Bavarian Alps (Map 1). It has a size of about $137 \mathrm{~km}^{2}$ and includes the villages of Hindelang, Bad Oberdorf, Vorderhindelang and Hinterstein with a total of 4840 inhabitants (including Ober- and Unterjoch outside the study area). The study area Hindelang consists of the valley of the mountain torrent River Ostrach, which has its source in the Allgäuer Alpen, a mountain range at the German-Austrian border. The catchment area of the Ostrach has elevations ranging from $780 \mathrm{~m}$ a.s.l. (Ostrach near Vorderhindelang) to $2594 \mathrm{~m}$ a.s.1. (Hochvogel), was glaciated in the Pleistocene and is characterised by large grazing areas between dense mountain forests. The geology is very complex. The southern part of the area belongs to the northern limestone Alps (with frequent debris flows events), whereas the lower northern part is characterised by the Flysch-zone, which is susceptible to slide events. The steep slopes all through the Ostrach valley support several small torrents tributary to the Ostrach. Especially in winter snow avalanches are regular for the southern part of the valley with elevations higher than $1400 \mathrm{~m}$ a.s.l. The mean annual precipitation rate is around $1630 \mathrm{~mm}$ (Hindelang station) with the highest monthly rates between June and August (more than $200 \mathrm{~mm}$ each month) as is typical for stations in the Bavarian Alps. The mean annual temperature is around $7^{\circ} \mathrm{C}$, ranging from $-2^{\circ}$ in January to $16^{\circ}$ in July. 


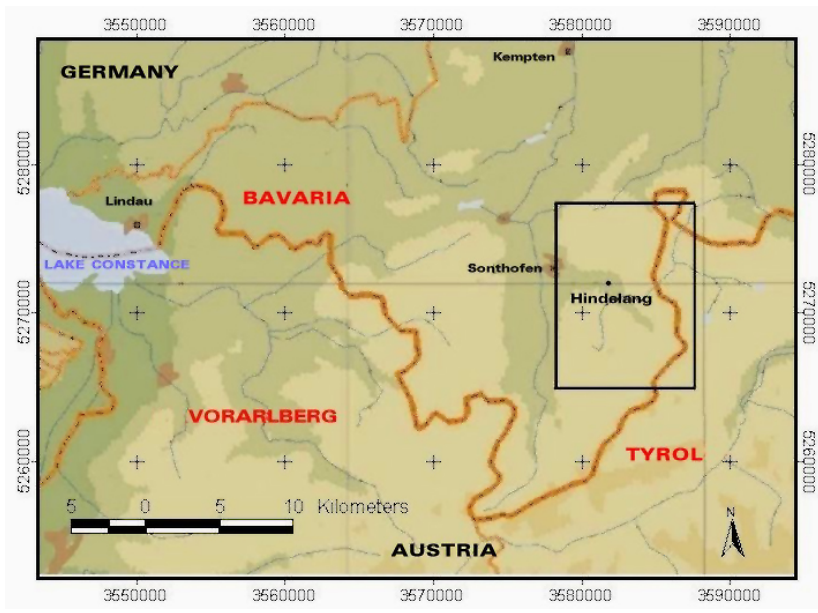

Map 1: Study area Hindelang of the HANG project.

Hindelang, the largest community in the Ostrach valley, was first mentioned in a document in 1150, but the area had been inhabited for at least three centuries at that time. It became an independent parish in 1435. The intensification of farming activities in the Allgäu region from the 17th century onwards led to an expansion of the settlements around Hindelang into endangered parts of the valley, thereby increasing the vulnerability of sites. Today, Hindelang is a favourite tourist spot both in summer and winter (for results from a comparable study area see Barnikel et al., 2003).

\section{The value of historical data}

The inclusion of past events in the local assessment of geodynamics is not new. Above all, it is the hydrologists who more and more seek to collect historical information, especially where modern science has not been able to provide them with sufficient data. The search for a strong basis of factual knowledge on a river system for example has become more widespread during the last two decades.

Data from historical times has been collected mostly for flood events of larger rivers, as was for example the case in Germany with Schiller (1987) and Glaser (1997) for the Main river and Pörtge and Deutsch (2000) for the Rhine. In Bohemia, to name but a few, Brazdil (1998) worked at the Elbe and Moldau rivers, Röthlisberger and Keller (1992) and Gees (1997) analysed floods in Switzerland, Sutcliffe (1987) worked in the UK, Coeur et al. (1998) in France, Barriendos et al. (2002) in France and Spain, Benito et al. (2002) in Spain, Calenda et al. (2002) along the Tiber and Henfling and Pflaumbaum (1991) searched for high water marks along the Nile.

Proxy data and written accounts for a more profound climatic knowledge beyond a sole analysis of floods and other hazardous events have been used all over the world by several scientists, for example by Ogilvie (1995) for Iceland, Camuffo and Enzi (1995) for Northern Italy, Borisenkov (1995) for Russia, Martín-Vide and Barriendos Vallvé (1995) for

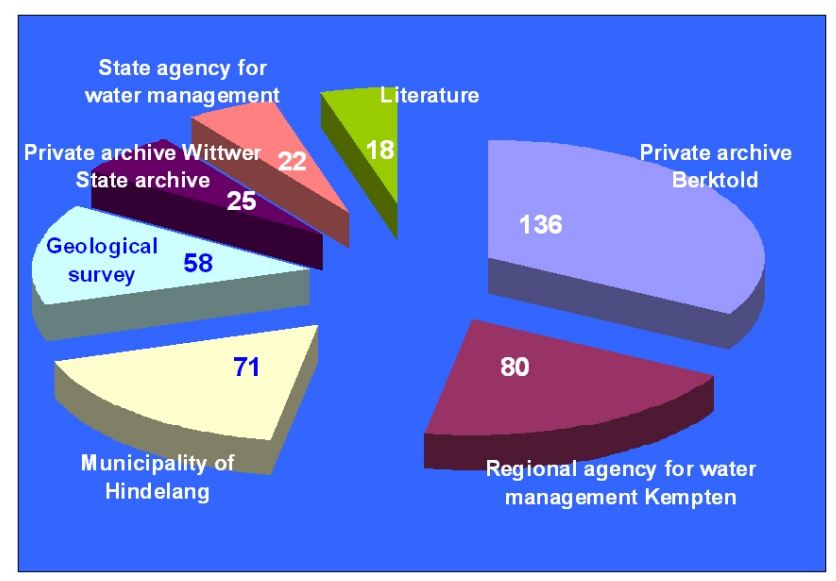

Fig. 1. Distribution of the total number of events for the different relevant archives.

Northern Spain, Ball (1995) for Canada, Wang and Zhang (1988) and Wang et al. (1991) for China, Nicholls (1988) for Peru and Australia, Pfister (1988, 1998), Pfister et al. (1988) and Pfister and Hächler (1991) for Switzerland and Fliri (1998) for Tyrol, Austria. Data from diaries for example have been collected by Glaser et al. (1991) for Madras, India and by Tagami (1991) for Japan. Glaser (2001) even constructed a climate atlas for central Europe out of written and proxy data.

In most cases the areas analysed in the papers mentioned above were very much larger than the small areas concentrated upon by the HANG project. The advantage of the HANG project is that the data gathered for a very limited region exactly shows the local hydrological and geomorphic dynamics, not a generalized picture of the area. The user of the resulting data bank gets precise and definite information about small scale catchment areas or individual places within the municipality in question, he does not have to draw conclusions from bigger scale assessments.

\section{Collecting the data}

In order to ensure a systematic research of all informative records all archives relevant for the projected regions have to be found and listed depending on their significance. Especially important are the archives of public authorities (like the administrative offices for hydrology and geology, local hydrological offices, archives of municipal authorities), furthermore forestry archives and private collections (chronicles, newspaper archives). Since many archives lack a modern and clearly structured registration, quite a lot of files need scrutinizing for references leading to documents describing hazardous events. The archive yielding most documents about flood events naturally was the archive of the local hydrological office. Although the archive is, on the whole, very well structured, the older documents are just kept in bundles. Therefore, the research work took a few weeks, but the result was convincing (Fig. 1). More time had to be spent in 


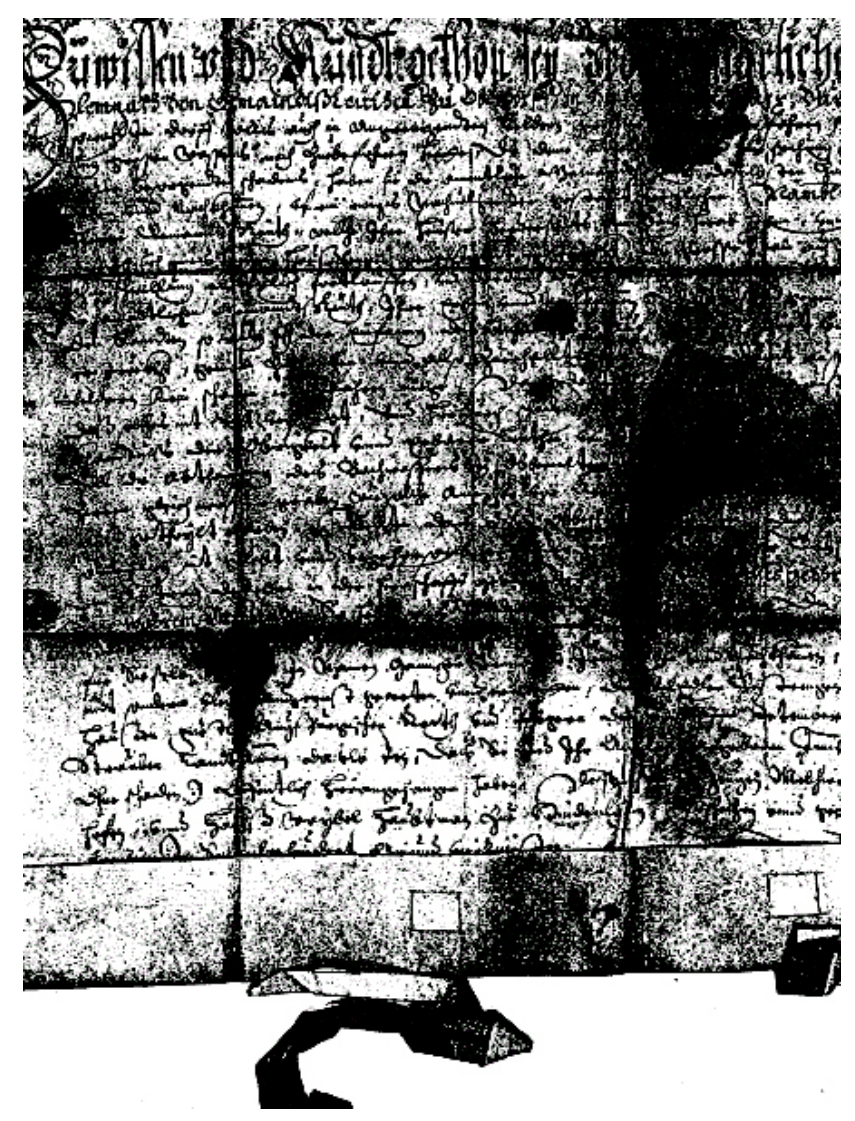

Fig. 2. Original document with references to local floods from 1644 (Municipality of Hindelang).

the archives of the municipality of Hindelang and the State Archive, where even less hints for the existence and whereabouts of relevant documents are existing.

The data collected (events larger than a specified threshold) is noted under certain aspects (time, place, kind of event, cause, extent, among others) in a specially designed registration sheet. A resulting data bank provides a systematic listing of all events collected. Due to the fact that most of the references dating back more than 30 or 40 years are hardly remembered by the people (as investigations of Wagner - oral communication - have shown), especially data from the past centuries are welcomed and have special significance. To gain sufficient data for evaluating flood risks a considerable amount of floods have to be assessed. Only far-reaching series for one river ensure an adequate interpretation of possible damaging effects. The enlargement of the chronological window moreover enables us to reduce the sampling uncertainty. The more information about one event we are able to collect, preferably data deriving from different types of archives, the better our basis for interpretation will become.

\section{Criticism of sources}

Historical written documents can roughly be divided into two types of documents. Most documents are official ones, with usually only short descriptions of the events but lengthy listings of occurred damages and, eventually, provisional measures for the future. Only few, but often very valuable documents are personal comments or even descriptions of the chronological process of an event. Some of the older documents are partly damaged (yellowed, torn) and hardly decipherable (Fig. 2). In both cases, the description of the event in question, the damages and the measures taken have to be analysed with caution. Some expressions in the texts like "the worst flood in history" are only of limited value, because people cannot remember most events once they date back more than about 40 years. Many documents, therefore, do not allow proper quantification, some do not even allow a satisfying localization. Baron (1995) calls this kind of data binominal data. With this data, e.g. a flood can be dated, described, evaluated and even categorised, but often "hard data" comparable to scientific measurements, like the amount of precipitation or the rate of discharge, is not available. Deductions can be made from the type of precipitation (like deluge or steady rain). Torrential rain is typical for mountainous areas and the high flow gradients of the torrential rivers lead to high peak discharges in short time. Usually a certain grade of localization is possible with some of the damaged fields, roads, bridges or houses known.

Among the different documents investigated by HANG, a wide variety concerning reliability and quality can be stated. Almost no document before the onset of scientific measuring provided objective data concerning volume, velocity, extension or the like (censored data) and more consist of data evaluated and praised by Baron (binominal data, 1995). Most documents only state the exceeding of a certain level of damage, for example the fact that a river left its bed, or damages to infrastructure, goods and people, which largely remain subjective and, in parts, unclear, like the fact that a certain bridge had been destroyed or that house number 49 was damaged. Although one can find the bridge and the house on ancient or recent maps, and, therefore, calculate the relative destruction a certain event must have had, an absolute measurement is not possible.

Especially older documents, however, show a pretty satisfying degree of precision among the "unscientific" data. Only events of some importance seem to have found entry in the archives and have been recorded precisely as a consequence. Whereas documents from administrative offices appear to have particularly well collected details about a certain event, even in the pre-instrumental period, older documents coming from municipal archives due to their legal character show a surprising quality when it comes to clearly stating place and time, and usually also intensity and reason for the event in question. The quality of data collected from Hindelang clearly support Wang and Zhang's (1988) and Baron's (1995) statement that written documents in many cases are more reliable than proxy data or even early scientific measurements.

Younger documents like texts from the offices for water management or from the municipalities are more precise overall. They often include instrumental records and were 


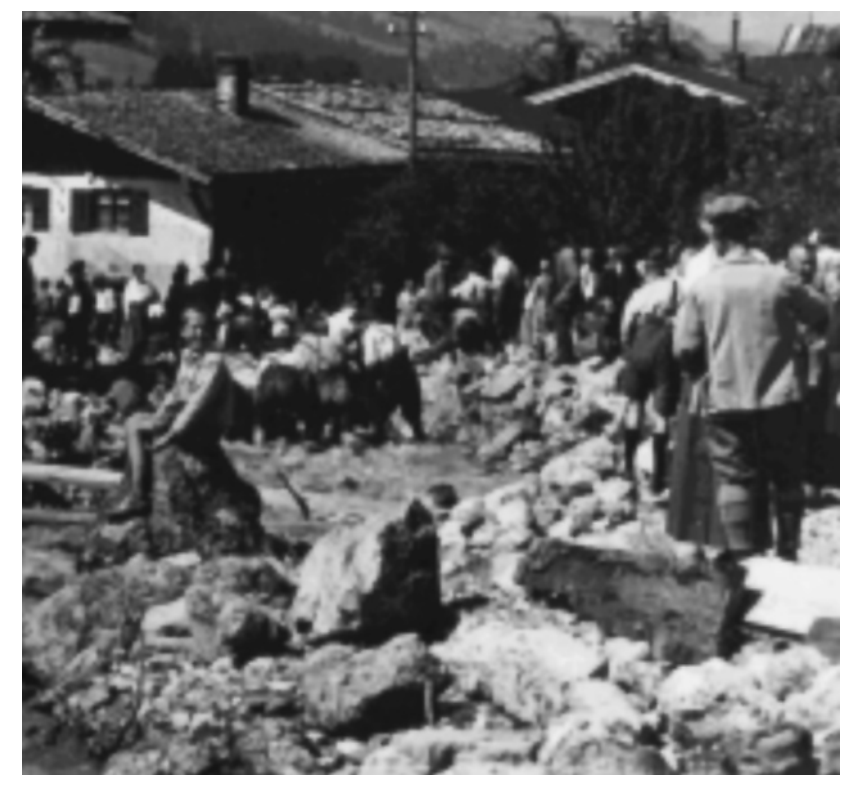

Fig. 3. Photograph of flood damage in Bad Oberdorf from 1924 (M. of Hindelang).

written by professionals in their fields. Remarks about the meteorological background or the chronology of the event become more frequent. In addition, photographs for some of the younger events show degrees of damage to houses and infrastructure and help evaluate the gravity of an event (Fig. 3). On the other hand, pictures are often taken once the event itself is over, so that the informational value of photographs is also limited. Last but not least one has to bear in mind that not all events find entry in written documents. One can assume that all graver events are documented, but especially the smaller ones do not always appear in historical documents. Many documents from the 15th to 18th century only state the month or year of an event, some are about reparations or measures for the future and only mention that an event had taken place so that there is no proper date available. It can be assumed that during these centuries some more events have taken place but were not recorded.

\section{Results}

The municipality of Hindelang has an archive reaching back to Renaissance times with a good number of old documents. But for most of the events in total references have been collected by a family of local chroniclers. More than $30 \%$ of a total of about 400 recorded references for events can be found in their collection of climatological dates (136 out of a total of 410). Around 50\% of the information gathered came from hydrological and geological offices (situated in Munich and Kempten) and the municipality of Hindelang (Fig. 1).

The bulk of events from the Hindelang area are flood events (251 references), much less are of geomorphic/geological nature (debris flows and landslides, 100 references), quite a few snow avalanches have also been

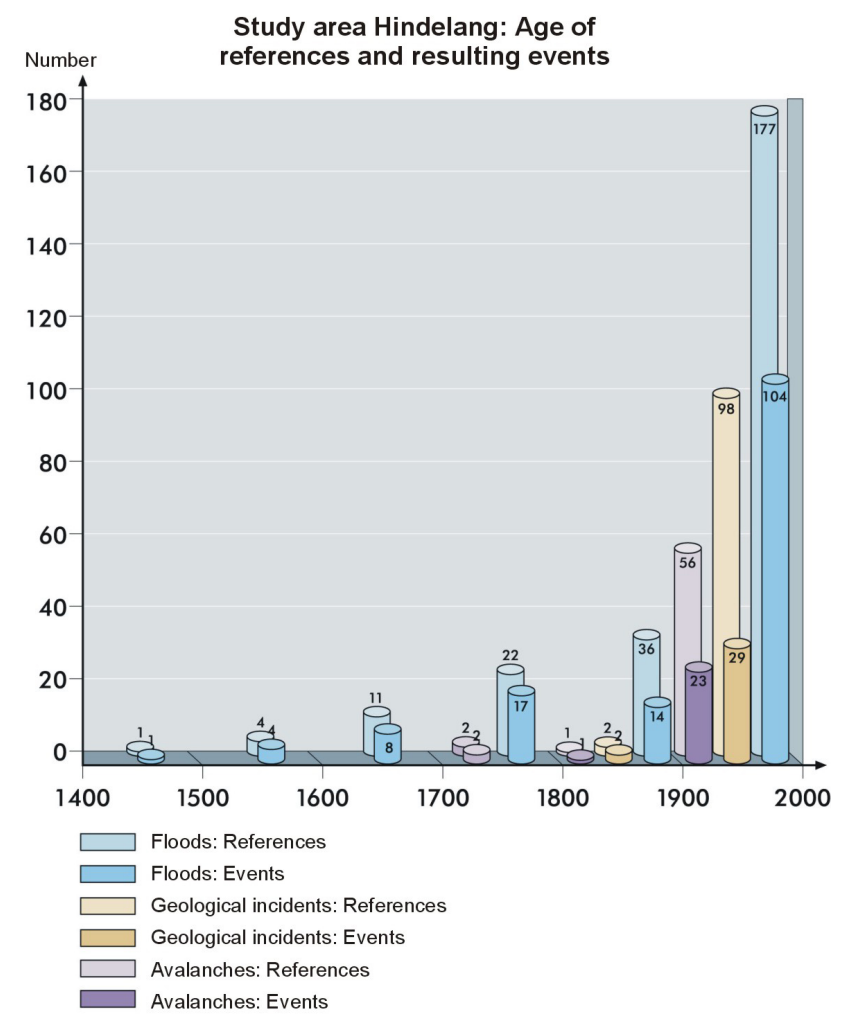

Fig. 4. Age of the references and the resulting events.

recorded (59 references). Naturally most of the damage occurs with floods, since the villages usually centre around bridges or fords crossing the rivers, and are therefore vulnerable. Geomorphic/geological events and avalanches usually tend to happen in areas with less inhabitants and thus are not always considered worth reporting.

About two thirds of all references for hazardous flood incidents (177 out of 251) have been found for the 20th century. Since the foundation of state run offices for water management in Bavarian provinces in the latter half of the 19th century the registration of natural disasters connected with rivers has dramatically improved. Consequently, the fact that we recorded more findings from the more recent centuries compared to earlier times not necessarily means that there are in fact more hazardous incidents nowadays, it has to be understood as a sign of better registration owing to the administration and the greater interest of people in natural hazards due to growing awareness. Additionally, more people have settled in endangered areas and more goods are threatened. 70 references date back to the first half of the 20th century, where a lot of documents have been lost due to World War II (Fig. 4).

Most documents about geomorphic/geological events and avalanches came from the 20th century, only very few references are older. With both kinds of disaster an exact dating is often impossible. Once a damage occurred, the event may be remarked in a written document, but there is usually only a terminus ante quem. 
Very desirable are documents from different archives, parallelly shedding light on the same event. Unfortunately more than $80 \%$ of the events have only been mentioned in one single document. Only younger events have found entry in more than one archive and are, consequently, better substantiated. As a consequence, as many archives as possible need scrutinizing for singular references to hazardous events. The older documents are nevertheless of special importance since they tell us something about the continuity of natural disasters in the area.

More than $50 \%$ of all data for Hindelang were of at least satisfying degree. That means that a concrete date for an event was given and in addition more details regarding origin, cause, damages and/or consequences. In about $15 \%$ of all references only a date was given with the remark that an event had taken place, but no further explanation or clarification were given. Still, even these simple remarks, especially when coming from older documents, give evidence of the activity of a certain river. Nevertheless, it must be stated that in several cases the documentary evidence for an event is comparably slight, these dates have to be treated with caution.

\section{Forms of application}

In a first step the events are classified after their gravity. Avalanches are divided into three groups, the ones with yearly occurence in group 1, avalanches occuring once in ten years in group 2, and avalanches less than once in ten years in group 3. The geomorphic/geological events are summed up in areas especially susceptible to slides or debris-flows. Floods are divided into five classes after the degree of the damage done (with class 5 being the highest, meaning destroyed houses and infrastructure, and class 1 being the lightest one, meaning just high water without any known damage). A grouping of the rivers according to the gravity of their specific flood events yielded four different classes of river activity. A first result of the classification is a map of historical natural hazards (Map 2).

A second step is the visualization of well documented events. All concrete references are combined in one data sheet per locality to show the degree of gravity for a given event at a certain place or in the whole region. Most references describe flood events, but in some cases there are also geomorphic/geological incidents recorded as part of a bigger event. The resulting maps show the number of documented damages and their exact localization (Maps 3 and 4).

The advantage of such a map is that the extent of an event can be seen at a glance. The next step follows, if localizations of damages seen on the map are yet unknown (or forgotten) and thus new to the reader. One can in this case check the dotshape-file which is connected with the data bank, where each damage has been recorded and listed. Together with the map of historical natural hazards the maps for certain events show areas in danger of frequent hazards. Additionally, the mountain torrents are listed in order of their dangerousness. Some of the torrents have not caused floods for several decades, but used to be dangerous earlier in the last century. In some cases the torrents have been blocked or dams have been built. But in other cases, the natural situation of the vicinity is just as it was decades ago. Some torrents are only dangerous if heavy rain occurs in their catchment area. The miniature size of the catchment area may be the reason, why only rarely flood events appear in this torrent.

A well documented event shook Oberdorf in the summer of 1851. Many damages have been listed and 80 years later an employee with the Regional Agency for Water Management drew a map with the extent of the floods in 1851 and 1901 (Map 5). HANG-Data-Bank (HDB) Sheet No. 520 reports: "The mountain torrent left its river bed and destroyed a large part of the village and many fields. All rooms in the houses were filled with water, the inhabitants alone were able to get away from the flood in time. Almost all houses were filled up with stones, sand and soil up to the upper floors. The bridge in Bruck, undamaged for more than 100 years, has been swept away." This quotation not only gives evidence for the enormous damage done to the village (exact localizations follow in the document), it also gives us an idea of how frequent a disaster of this kind has happened in the area. An old bridge, unharmed for more than 100 years, has been not only damaged but destroyed completely. The ground floor of House No. 52 in Oberdorf was completely filled with debris, which caused the inhabitants to fully move entrance and all rooms which used to be on the ground floor to the first floor. By the help of old cadastral maps the extent of the flood of 1851 could be easily tracked and mapped.

A comparable event was the flood of 1924 (Map 4, Fig. 3). HDB Sheet No. 449 gives the exact places where damages occured and enables a comparably useful mapping. It also mentions the written sources which name the reason for the flood ("deluge"), the exact time ("after 16:30 PM"), and a kind of chronology ("the torrent first destroyed the riverside of House No. 57, then followed the road down to House No. 32" and so on). Endangered objects are named, so are the consequences which were demanded. (Other parts of the Ostrach valley are described, e.g. in the HDB Sheets Nos. 447, 451, 452, 578, 750, and 751.)

Apart from visualising the documented events, one can compare the data with data in existing data bases. Responsible for the torrents of Hindelang is the Regional Agency of Water Management in Kempten, an administrative office of the Bavarian Ministry of Environment. This agency started in 1999 to file all events in a specially designed data bank. When the HANG project started in 2000, only two events had found entry so far. HANG added another 148 events from six centuries to the existing data bank. Many torrents show activity only once in a while, in many cases less than once in a decade. In order to properly assess activity and dangerousness of torrents also older events have to be included.

For the existing geo risk data bank of the Bavarian Geological Survey HANG added nine localities with sometimes frequent hazardous events. To the existing cadastral survey of avalanches in the Bavarian State Agency for Water Management HANG contributed 17 new avalanche tracks. 


\section{Historical Map of Natural Hazards}

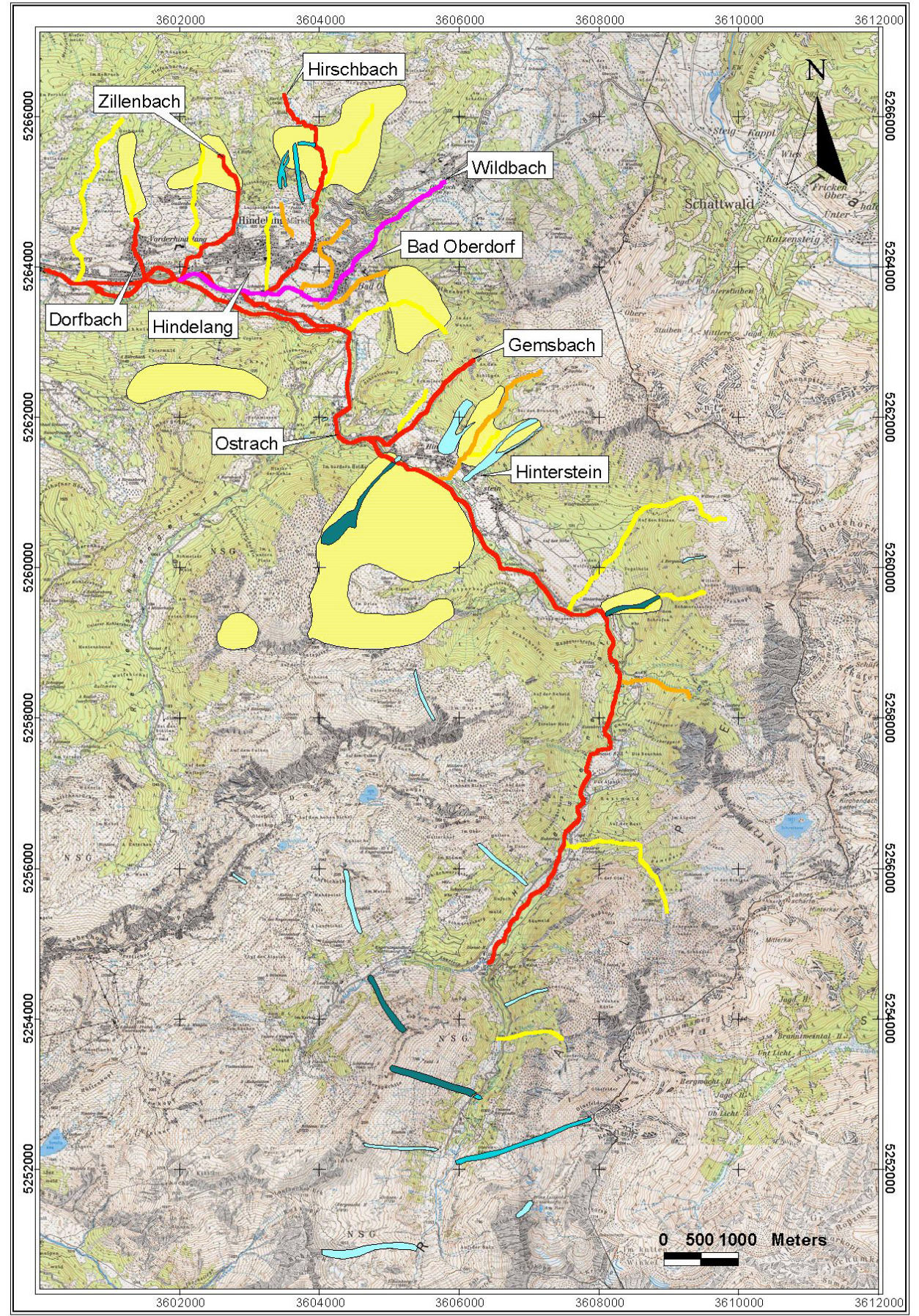

$\checkmark$ Extremely active river

$\wedge$ Highly active river

Area susceptible to mass movement

Avalanches

Active river

Class I: yearly occurence

Rarely active river

Class II: occurence at least once in ten years

Class III: occurence less than once in ten years

Map 2: Map of natural hazards established from historical documents. 


\section{Flood of 1851}
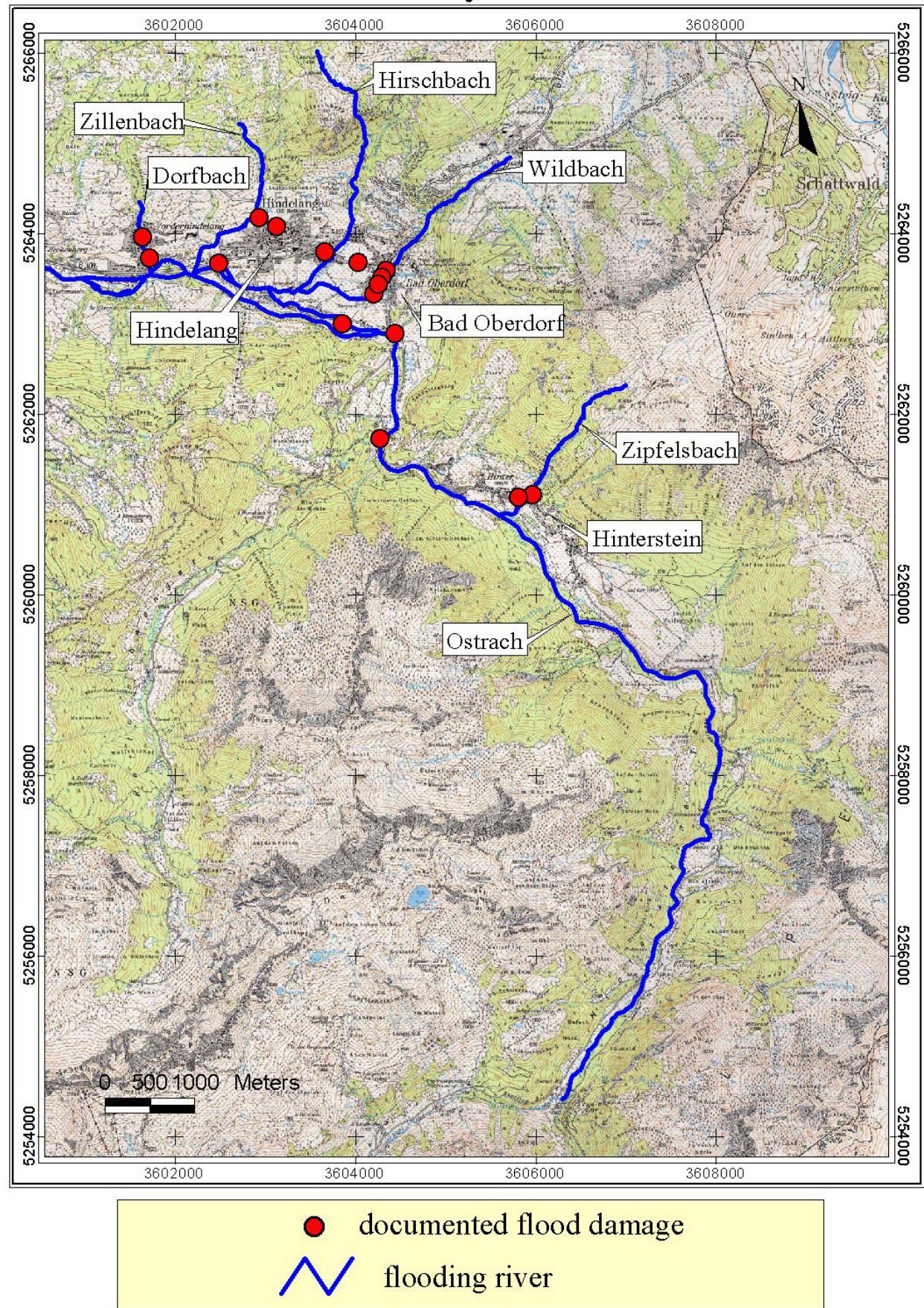

Map 3: The flood of 1851.

Data from HANG, therefore, definitely substantially adds to a better understanding of processes in alpine environments and are highly appreciated by the responsible state offices. Since there is no existing data base including historical data for the Bavarian Alps which could be used by engineers and planners, data from HANG are a valuable source, especially when concerning rivers, for politicians and hydrologists alike.

\section{Comparison with data from adjoining areas}

As to the question of recurrence, HANG data indicate that, beyond any actually known event, severe floodings and slides have occurred not regularly but, still, every once in a while during the last five centuries. In Hindelang, for example, we have evidence for heavy floods among others in 1435, 1582, $1641,1749,1787,1846,1851$, to name but a few incidents 


\section{Flood of 1924}

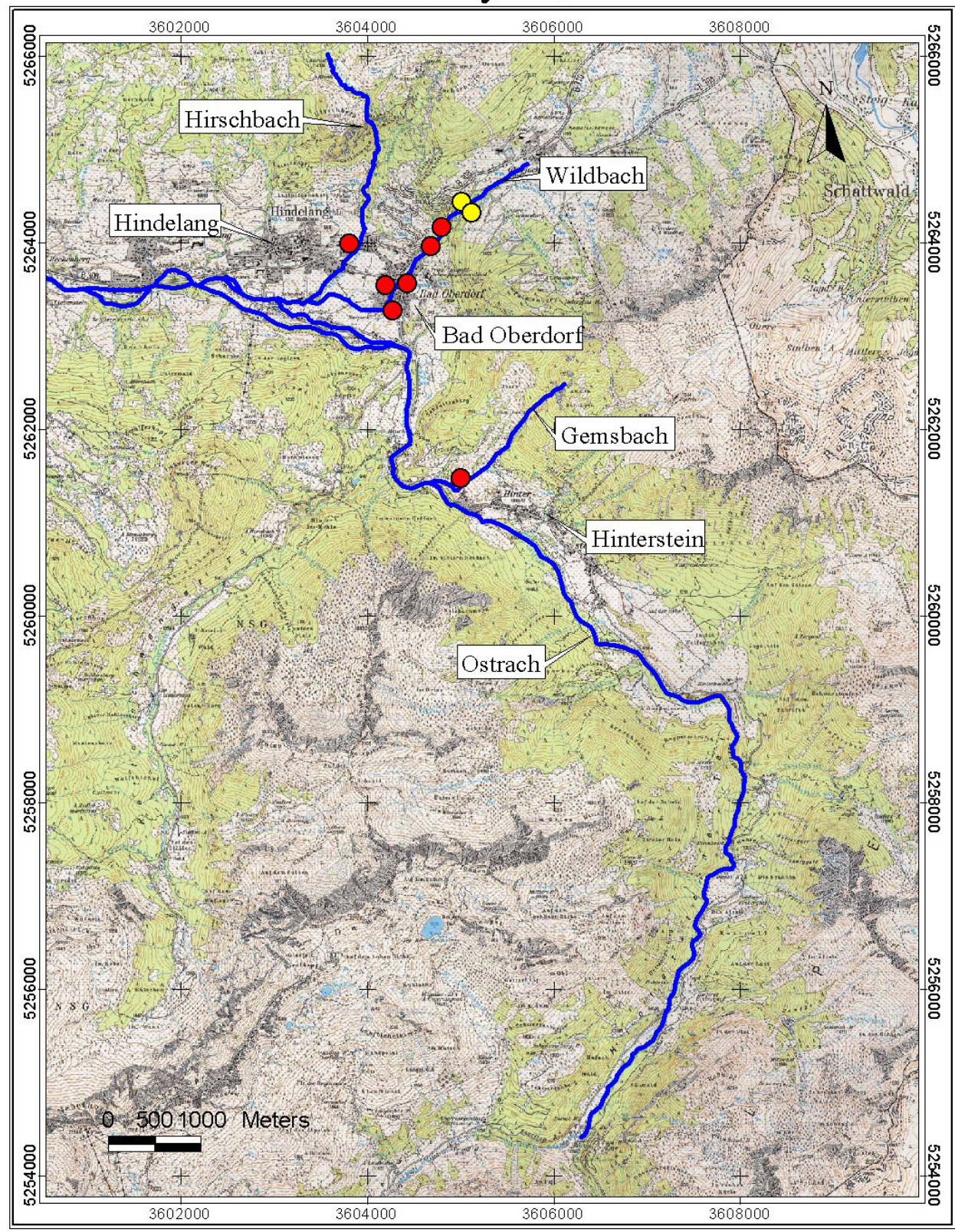

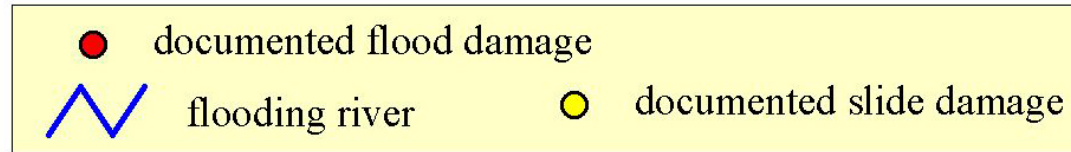

Map 4: The flood of 1924.

from earlier centuries. Some flood events, like the ones in $1584,1680,1733,1749,1851$ and others correspond well with the data collected by Fliri (1998) for the adjoining areas in Austria. Flood events in 1878, 1879, 1905 and some more can be found in eastern Switzerland as well, judging from the data published by Pfister (1998).

Comparisons with precipitation data from weather stations within the study areas and eleven stations outside (between Salzburg in the east and Zurich in the west, Munich in the north and Bolzano in the south, the oldest of which started recording in the second half of the 19th century) show parallels of high precipitation rates with flood event data from Hindelang in many cases, but not automatically. Sometimes the stations with the greatest distance recorded high precipi- 


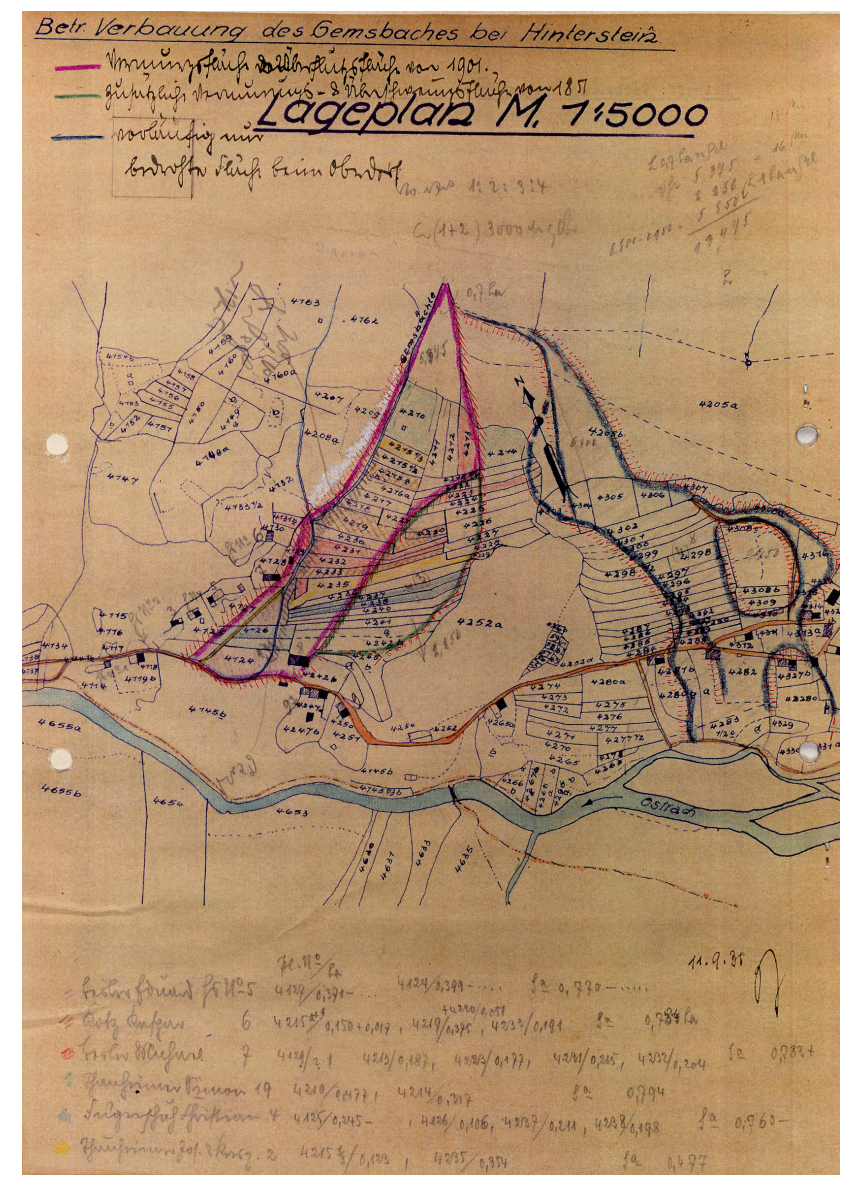

Map 5: Original map for flood events in Hinterstein in 1851 and 1901 (Regional agency for water management Kempten).

tation, while stations adjoining to the study area were inconspicuous. In these cases a greater area of precipitation as that of mediterranean cyclones is probable. In some parts of the precipitation area the precipitation rates were high enough to trigger off a flood, in others the amount of water was too small. Many cases, on the other hand, show precipitation rates beyond $100 \mathrm{~mm} /$ day in the study areas, while neighbouring valleys only received 20 to $30 \mathrm{~mm} /$ day. In all cases where flood events were caused by thundershowers, the precipitation rate, if known, was around $100 \mathrm{~mm}$ or more for the whole day.

Judging from the comparison between the HANG data, the historical data from neighbouring areas and the precipitation lists from weather stations one can conclude that the historical data are precise regarding the date and the gravity of an event. They have been confirmed by numerous data from all stations. But on the whole the events recorded for the study area show a high degree of locality. Consequently, a lot of flood events can only be found locally, with no reference to other areas, or even countries, like the ones in 1641,1781 or 1807. Consequently, flood events in other areas found no entry in documents researched by HANG, like the flood catastrophe in Switzerland in the early October of 1789 (see Pfister, 1998). On the whole only a small percent- age of concrete dates of flood events in Hindelang show parallels with dates from neighbouring areas. Of the 113 dates investigated 71 are concrete days where flood events took place. Out of these 71 dates only seven correspond exactly and 14 correspond satisfactory with data from nearby Tyrol (see Fliri, 1998). The remaining 50 dates have no parallels in the neighbouring Tyrolean areas (data from more remote parts of Tyrol have not been considered). The best data from Switzerland comes from Gees (1997). From regions nearby (the area around Graubünden, Appenzell and St. Gallen) five good and ten satisfying parallels have been found for the 71 dates. The fact that considerably less dates correspond with the HANG dates is due to the greater distance of the compared areas. Other comparisons with data from Switzerland (Röthlisberger, 1991) and Germany (Glaser, 2001) show even less parallels because of the growing distance between Hindelang and the other regions. On top of that it must be stated that not only the gravest events found parallels in adjoining areas. In some cases catastrophic events had no parallels in the neighbouring valleys, whereas some minor floods found good parallels in Austria or Switzerland.

It has to be concluded that small catchment areas in the Bavarian Alps react individually on climatic phenomena. Fronts do not show the same impact even on neighbouring valleys, and thunderstorms in the summer from cumulonimbus clouds are of limited extension anyway. The question of clearly recognizable recurrence intervals has to be asked, and a specific statistical framework should be used with historical information, considered as censored data (see Stedinger and Cohn, 1986).

A comparison with concentrations of flood events from central European rivers in Sturm et al. (2001) shows that the periods with more frequent and severe floodings in Hindelang (Fig. 5) does not compare to the more active periods of large river systems (Main, Rhine, Saale, Elbe, Weser). Moreover, the majority of severe floods of large river systems occured in the winter, while in Hindelang, as is the case with most Alpine catchment areas, the floods regularly occured in the summer. Apart from that, the sizes of the catchment areas are totally different. The catchment areas of Alpine torrents in the Ostrach valley often cover less than $1 \mathrm{~km}^{2}$. A fourth point to be kept in mind is that the type of precipitation leading to high water levels in the Alpine rivers is different from the rivers in subdued mountain ranges or the lowlands. In the Alps thundershowers prevail, which cause high precipitation rates in very short time. The run-off process is triggered off very quickly and the maximum discharge is sometimes reached within minutes. Floods in high- or lowlands, where the river systems are large, are only reached after several days of persistent rain (the meteorological conditions of the $\mathrm{Vb}$ situation after the classification of van Bebber is well known for heavy floodings downstream the Elbe for example).

As a consequence one can conclude from the results of the research work done by HANG:

- Hazardous events in Alpine catchments are usually limited to a small area, as sometimes large continental 


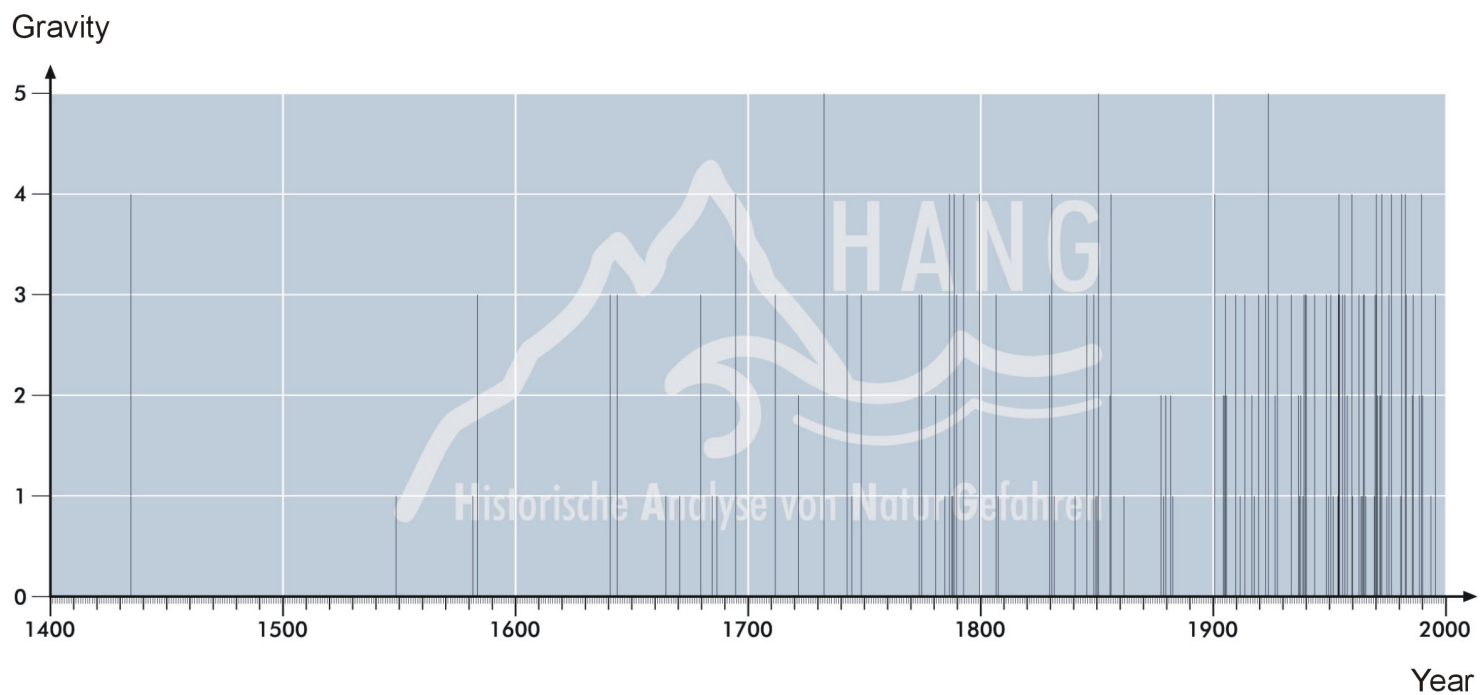

Fig. 5. Chronological distribution of flood events with respect to their severity.

events have affected both little and large basins.

- The events may only be investigated from documentary sources about this area, sources from other areas usually give no information about events in other regions.

- The date of an event is not transferable to the date of an assumed event in another area.

- No event may be deduced from a known event in a neighbouring area.

- The catchment areas in the Alps in most cases are very small and react individually on precipitation.

- No valid climatological trend for a larger region may be directly concluded from results gathered from small catchment areas. Only the assessment of several connected study areas may allow more general climatological statements.

\section{Outlook}

The data investigated and assessed by HANG from documentary sources are precise. They are confirmed by numerous data from weather stations and some parallel events from abroad. Since more than half of all documents offered at least satisfactory information on hazardous events, the method probed in the field can be characterised as valid. Most data has been collected for flood events, though also data for geomorphic/geological events and avalanches led to a surprising number of additions to complement existing official data bases. But it is foremost the Agencies for Water Management which profit from data distilled from documentary sources to enlarge their data bases. The majority of documents can be found in administrative archives, most of which unfortunately only offer data for the 20th century.
As a result, the search for older data in order to ensure a sufficient string of data for the assessment of the hazardous potential of a river always has to include non-administrative archives, such as private or municipal ones, and needs (with respect to the documents often being in an almost illegible state) cooperation with historians. Without intense interdisciplinary work on historical floods reconstructed by way of analysing written documents no satisfying results will be reached. With respect to the considerable operational benefits of the historical analysis of natural hazards we come to the conclusion that such analysis definitely has to be included in all further investigations of hydrological or geomorphic dynamics in inhabited mountainous regions.

Moreover, the monetary aspect has to be kept in mind. Blocking up mountain torrents in many cases already asks for six-figured amounts in Euro. If the dimension of damming or blocking is not adequate, few years later similar amounts have to be met, when the torrents are treated again. A thorough analysis of prominent areas, with total costs well below the sum mentioned above, will certainly help reduce the costs for hazard mitigation in the Alps.

Acknowledgement. HANG receives funding from the Bavarian Ministry of Environment.

\section{References}

Ball, T. F.: Historical and instrumental evidence of climate: Western Hudson Bay, Canada, 1714-1850, in: Climate Since A.D. 1500 (London) edited by Bradley, R. S. and Jones, P. D., p. 40-73, 1995.

Barnikel, F., Frank, C., and Becht, M.: "Natural hazard maps in the Alps derived from historical data on a local scale - Results from the Tegernsee valley (Bavaria, Germany)", in: Palaeofloods, Historical Data and Climatic Variability: Applications in flood risk assessment (Barcelona), edited by Thorndycraft, V. R., Benito, G., Barriendos, M. and Llasat, M. C., p. 155-160, 2003. 
Baron, W. R.: Historical climate records from the northeastern United States, 1640 to 1900, in: Climate Since A.D. 1500 (London), edited by Bradley, Raymond, S., and Jones, P. D., p. 74-91, 1995.

Barriendos, M., Coeur, D., Lang, M., Llasat, M. C., and Naulet, R.: Stationarity analysis of historical flood in France and Spain with a classification of events based on historical flood levels or damages, Geophysical Research Abstracts 4/2002, Abstracts of the Contributions of the 27th General Assembly of the European Geophysical Society, Nice, France, 21-26 April, 2002.

Benito, G., Rico, M., Sanchez-Moya, Y., Sopena, A., and Thorndycraft, V. R.: Magnitude and frequency of palaeofloods in the upper Guadalentin basin (SE-Spain) during the last 1000 years, Geophysical Research Abstracts 4/2002, Abstracts of the Contributions of the 27th General Assembly of the European Geophysical Society, Nice, France, 21-26 April, 2002.

Borisenkov, Y. P.: Documentary evidence from the U.S.S.R., in: Climate Since A.D. 1500 (London), edited by Bradley, R. S. and Jones, P. D., p. 171-183, 1995.

Brázdil, R.: The history of floods on the rivers Elbe and Vltava in Bohemia, in: Aktuelle und historische Hochwasserereignisse (Erfurter Geographische Studien 7; Erfurt), edited by Pörtge, K.H. and Deutsch, M., p. 93-108, 1998.

Calenda, G., Calvani, L., Mancini, C. P., and Volpi, E.: Reconstruction of the extreme flood series of the Tiber river in Rome from the XV. century, Geophysical Research Abstracts 4/2002, Abstracts of the Contributions of the 27th General Assembly of the European Geophysical Society, Nice, France, 21-26 April, 2002.

Camuffo, D. and Enzi, S.: Reconstructing the climate of northern Italy from archive sources, in: Climate Since A.D. 1500 (London), edited by Bradley, R. S. and Jones, P. D., p. 143-154, 1995.

Coeur, D., Lang, M., Naulet, R., Burnet, R., and Strazzeri, D.: Histoire et connaissance des phénomenes naturels extremes, Ingénieres-EAT, p. 15-26, 1998.

Fliri, F.: Naturchronik von Tirol (Innsbruck), 1998.

Gees, A.: Analyse historischer und seltener Hochwasser in der Schweiz (Geographica Bernensia, G 53; Bern), 1997.

Glaser, R.: Historische Hochwässer im Maingebiet - Möglichkeiten und Perspektiven auf der Basis der historischen Klimadatenbank Deutschland (HISKLID), in: Aktuelle und historische Hochwasserereignisse (Erfurter Geographische Studien 7; Erfurt), edited by Pörtge, K.-H. and Deutsch, M., p. 109-128, 1997.

Glaser, R.: Klimageschichte Mitteleuropas (Darmstadt), 2001.

Glaser, R., Militzer, S., and Walsh, R.: Weather and climate at Madras, India, in the years 1732-1737 based upon an analysis of the weather diary of the German missionary Geisler, Würzburger Geographische Arbeiten 80, p. 45-86, 1991.

Henfling, E. and Pflaumbaum, H.: Neue Aspekte zur klimatischen Interpretation der hohen pharaonischen Nilflutmarken am 2. Katarakt aus ägyptologischer und geomorphologischer Sicht, Würzburger Geographische Arbeiten 80, p. 87-109, 1991.

Martín-Vide, J. and Barriendos Vallvé, M.: The use of rogation ceremony records in climatic reconstruction: A case study from Cat- alonia (Spain), Climatic Change, 30, p. 201-221, 1995.

Nicholls, N.: More on early ENSOs: Evidence from Australian documentary sources, Bulletin of the American Meteorological Society, 69/1, p.4-6, 1988.

Ogilvie, A. E. J.: Documentary evidence for changes in the climate of Iceland, A.D. 1500 to 1800, in: Climate Since A.D. 1500 (London), edited by Bradley, R. S. and Jones, P. D., p. 92-117, 1995.

Pfister, C.: Klimageschichte der Schweiz 1525-1860 (Academia Helvetica 6; Bern), 1988.

Pfister, C.: Raum-zeitliche Rekonstruktion von Witterungsanomalien und Naturkatastrophen 1496-1995 (Schlussbericht NFP 31; Zürich), 1998.

Pfister, C. and Hächler, S.: Überschwemmungskatastrophen im Schweizer Alpenraum seit dem Spätmittelalter, Würzburger Geographische Arbeiten 80, p. 127-148, 1991.

Pfister, C., Bütikofer, N., Schuler, A., and Volz, R.: Witterungsextreme und Waldschäden in der Schweiz (Bern), 1988.

Pörtge, K.-H. and Deutsch, M.: Hochwasser in Vergangenheit und Gegenwart, Rundgespräche der Kommission für Ökologie 18, p. 139-151, 2000.

Röthlisberger, G.: Chronik der Unwetterschäden in der Schweiz (Berichte der Eidgenössischen Forschungsanstalt für Wald, Schnee und Landschaft 330; Birmensdorf), 1991.

Röthlisberger, G. and Keller, H. M.: Historische Hochwasser in der Schweiz - Ursachen und jahreszeitliche Verteilung, Interpraevent 1992/1, p. 105-116, 1992.

Schiller, H.: Ermittlung von Hochwasserwahrscheinlichkeiten am schiffbaren Main und überregionaler Vergleich der Ergebnisse", Beiträge zur Hydrologie, Sonderheft 6 (Kirchzarten), p. 79-101, 1987.

Stedinger, J. R. and Cohn, T. A.: Flood frequency analysis with historical and paleoflood information, Water Resources Research, 22/5, p. 785-793, 1986.

Sturm, K., Glaser, R., Jacobeit, J., Deutsch, M., Brázdil, R., Pfister, C., Luterbacher, J., and Wanner, H.: "Hochwasser in Mitteleuropa seit 1500 und ihre Beziehung zur atmosphärischen Zirkulation”, Petermanns Geographische Mitteilungen 145, p. 14-23, 2001.

Sutcliffe, J. V.: The use of historical records in flood frequency analysis, J. Hydrology, 96, p. 159-171, 1987.

Tagami, Y.: Some aspects of climatic variation in Japan from the 17 th to the 19th centuries - An attempt at reconstruction based on data from diaries, Würzburger Geographische Arbeiten 80, p. 241-251, 1991.

Wang, P. and Zhang, D.: An introduction to some historical governmental weather records of China, Bulletin of the American Meteorological Society, 69/7, p. 753-758, 1988.

Wang, R., Wang, S., and Fraedrich, K.: An approach to reconstruction of temperature on a seasonal basis using historical documents from China, International Journal of Climatology, 11, p. 381-392, 1991. 